Colloquia Litteraria

UKSW

$2 / 2015$

KATARZYNA GĘDAS

\title{
KRÓL-DUCH JULIUSZA SŁOWACKIEGO W RECEPCJI JAROSŁAWA IWASZKIEWICZA
}

Król-Duch Juliusza Słowackiego miał dla Jarosława Iwaszkiewicza szczególne znaczenie. Dzieło to było dla niego jednym z najważniejszych i „najbliższych w literaturze romantycznej, a może nawet w ogóle w całej polskiej literaturze"1. Wrażenia z lektury odnotowywał w swoich utworach literackich i publicystycznych, dziennikach, korespondencji oraz w formie marginaliów.

Dzieło Słowackiego silnie naznaczyło szczególny okres w życiu Iwaszkiewicza, gdy wiosną 1918 roku służył w III Korpusie Polskim na Ukrainie. Poemat czytał wówczas wspólnie ze swym bliskim przyjacielem Mieczysławem Kozłowskim na wzgórzach nad rzeką Boh, pokrytych kwitnącymi fiołkami. Wrażenia te zapisał w utworze Nasza droga ${ }^{2}$ w formie ,impresjonistycznych migawek”. Król-Duch zestawiony został z zieloną strugą, kwaśnym mlekiem, wschodem słońca. Poemat Słowackiego w pisany był w codzienność wojskowego życia młodego żołnierza:

Konserwy z chlebem wśród palącego wiatru. O zmierzchu zatrzymanie przed oknem na uśpiony łuk stalowej nieruchomej rzeki. Stajnie i nocne warty. Król Duch i fiołki na zboczach wzgórz. Polowanie na wszy na łące wiosennej nad zieloną strugą. Nocleg na słomie po obżarciu się kwaśnym mlekiem. Wschód słońca poprzez czereśnie kwitnące;

Kwiecieńn ${ }^{3}$.

1 Jarosław Iwaszkiewicz, Książka moich wspomnień, Warszawa 1975, s. 152.

2 Utwór pochodzi z tomu Kasydy zakończone siedmioma wierszami (1925), w skład którego wchodzą teksty napisane w latach 1917-1919.

3 Jarosław Iwaszkiewicz, Nasza droga, w: tegoż, Wiersze, t. 1, Warszawa 1977, s. 140. 
Wspomnienia z lektury Króla-Ducha podczas służby wojskowej Iwaszkiewicz powtórzył później w zbiorze opowiadań Pejzaże sentymentalne ${ }^{4}$, a następnie w Książce moich wspomnień:

Siadywaliśmy na nich [wzgórzach] godzinami z szarą książką Słowackiego i studiowaliśmy od deski do deski ciemny, zawiły, ale jakże poetycki poemat, rapsod po rapsodzie. Kontrast naszego otoczenia, brutalność nocy, spędzanych na warcie lub w stajniach przy pilnowaniu koni [...] stanowił jeszcze o jeden powab więcej tej ciepłej, pachnącej i groźnej wiosny ${ }^{5}$.

Opis zawarty w ocalałych fragmentach pamiętników Iwaszkiewicza pochodzących z 1921 roku jeszcze wyraźniej akcentuje emocjonalny stosunek pisarza do poematu Słowackiego:

Wciąż wracaliśmy z pełnym sercem entuzjazmu do tych strof wiążących niebo z ziemią i doznawaliśmy każdej z nich jak rozkoszy. Jest to jedyne dzieło, które w ten sposób czytałem ${ }^{6}$.

W korespondencji z żoną Anną pisarz podkreśla, że jego przyjaciele skamandryci nie podzielali tego entuzjazmu i nie doceniali Słowackiego. W liście z 1 września 1923 roku notuje:

[...] wczoraj siedliśmy sobie wieczorkiem w Ziemiańskiej i mówiliśmy wiersze: Leszek ${ }^{8}$, Tuwim i ja. Oni mają taką cudowną pamięć, świetnie mówią i to z najrozmaitszych dziedzin: i Puszkina, i Mickiewicza, i współczesnych. Tylko to dziwne, że oni Słowackiego nie lubią, zupełnie tego nie rozumiem. Chciałbym im pokazać pewne strofy

\footnotetext{
4 Por. Jarosław Iwaszkiewicz, Pejzaże sentymentalne, w: tegoż, Proza poetycka, Warszawa 1980, s. 315-316.

5 Jarosław Iwaszkiewicz, Książka moich wspomnień, dz.cyt., s. 152.

6 Jarosław Iwaszkiewicz, Dzienniki 1911-1955, oprac. Agnieszka i Robert Papiescy, Warszawa 2007, s. 116.

7 Ziemiańska - kawiarnia warszawska, miejsce spotkań skamandrytów.

8 Leszek Serafinowicz (pseud. Jan Lechoń).
} 
w Królu-Duchu, ale nie mam go pod ręką. Im to niestety nic nie mówi. To dziwne, ta obojętność naszego pokolenia względem Słowackiego 9 .

O poemacie Słowackiego myślał także, będąc we Francji. Podczas przechadzki o świcie ulicami Paryża, mijając avenue de l'Observatoire, uświadomił sobie, że znajduje się w miejscu, w którym kiedyś autor Króla-Ducha zastanawiał się nad treścią kolejnych strof swego nieukończonego dzieła. Siódmego maja 1925 roku w liście do żony Iwaszkiewicz zrelacjonował to przeżycie: „[...] aż mi się strasznie zrobiło, że to są te same bruki, po których chodząc Słowacki obmyślał Króla-Ducha [...]"10. Ślady obecności Słowackiego odnalazł także podczas podróży do Rzymu w czerwcu 1960 roku, zapisał wówczas w dzienniku: „Dużo myślę o Słowackim. Patrzyłem na jego tablicę na via Babuino ${ }^{11}$. [...] Trzeba go znowu poczytać: może mi przywróci młodość"12.

Iwaszkiewicz patrzył na poemat Słowackiego także okiem publicysty. Pięciokrotnie pisał o Królu-Duchu na łamach prasy - w latach 20. w „Wiadomościach Literackich” oraz w latach 70. w „Życiu Warszawy”. W dwóch pierwszych recenzjach ${ }^{13}$ dotyczących krytycznego wydania poematu w opracowaniu Jana Gwalberta i Michała Pawlikowskich ${ }^{14}$ przeprowadza szczegółową analizę komentarza edytorskiego oraz

9 Anna i Jarosław Iwaszkiewiczowie, Listy 1922-1926, oprac. Małgorzata Bojanowska, Ewa Cieślak, Warszawa 1998, s. 97.

10 Tamże, s. 395.

11 Juliusz Słowacki w 1836 r. mieszkał w Rzymie przy via Babuino 165. W 1959 r. umieszczono w tym miejscu tablicę pamiątkową.

12 Jarosław Iwaszkiewicz, Dzienniki 1956-1963, oprac. Agnieszka i Robert Papiescy, Radosław Romaniuk, Warszawa 2010, s. 394.

13 Por. Jarosław Iwaszkiewicz, Pomnikowe wydanie «Króla-Ducha», „Wiadomości Literackie” 1924, nr 47, oraz tegoż, Wydanie zupetne «Króla-Ducha», „Wiadomości Literackie" 1925, nr 39.

14 Mowa o wyd.: Juliusz Słowacki, Król-Duch, t. 1-2, oprac. Jan Gwalbert Pawlikowski, Michał Pawlikowski, Lwów (t. 1 - 1924; t. 2 - 1925).

Jan Gwalbert Pawlikowski (186o-1939) - ekonomista, polityk, społecznik; badacz i popularyzator twórczości Słowackiego; Michał Pawlikowski (1878-1970) - pisarz i wydawca, syn Jana Gwalberta. 
dzieli się swoimi wątpliwościami co do niektórych zastosowanych przez Pawlikowskich rozwiązań i proponowanych interpretacji.

Inny charakter ma artykuł będący szkicem porównawczym Króla-Ducha Juliusza Słowackiego i W poszukiwaniu straconego czasu Marcela Prousta ${ }^{15}$. Iwaszkiewicz uważa, że obaj pisarze w ten sam sposób pojmowali koncepcję osobowości, którą widzieli jako proces składający się z poszczególnych faz. U Prousta proces ten przebiega na planie podświadomości „od kolebki do śmierci”, u Słowackiego natomiast w „kulisach zaświatowości” rozłożony jest na kilka żywotów.

Niemal pięćdziesiąt lat później Iwaszkiewicz recenzuje na łamach „Życia Warszawy”" kolejne krytyczne wydanie Króla-Ducha ${ }^{17}$. $\mathrm{W}$ artykule dokonuje zestawienia tego wydania $\mathrm{z}$ wydaniem Pawlikowskich i omawia zasady, którymi kierowali się edytorzy, oraz trudności, jakie napotkali. Pojawienie się tego wydania odnotował także w dzienniku ${ }^{18}$.

Uwadze recenzenta nie umknęło także pojawienie się kolejnego tomu Dzieł wszystkich, zawierającego warianty poematu Słowackiego. Krytyczna edycja ukazuje się w 1975 roku $^{19}$ i także zostaje zrecenzowana w „Życiu Warszawy”.

Ślady lektury Króla-Ducha znajdujemy także w archiwum pisarza w Muzeum im. Anny i Jarosława Iwaszkiewiczów w Podkowie Leśnej. Jest tam dwutomowe wydanie poematu Słowackiego w opracowaniu Pawlikowskich, zawierające marginalia Iwaszkiewicza. Notatki

15 Por. Jarosław Iwaszkiewicz, Słowacki i Proust, „Wiadomości Literackie” 1927, nr 26; publ. pod pseud. Eleuter.

16 Por. Jarosław Iwaszkiewicz, Tom XVI, „Życie Warszawy” 1973, nr 84.

17 Mowa o wyd.: Juliusz Słowacki, Król-Duch. Rapsody nie wydane za życia poety. Tekst główny, oprac. Jan Kuźniar, w: Juliusz Słowacki, Dzieła wszystkie, pod red. Juliusza Kleinera i Władysława Floryana, t. XVI, Wrocław 1972.

18 Por. Jarosław Iwaszkiewicz, Dzienniki 1964-1980, oprac. Agnieszka i Robert Papiescy, Radosław Romaniuk, Warszawa 2011, s. 336.

19 Mowa o wyd.: Juliusz Słowacki, Król-Duch. Opracowania odmienne rapsodów $I-I V$, przygotował Jan Kuźniar z udziałem Władysława Floryana, w: Juliusz Słowacki, Dzieła wszystkie, pod red. Juliusza Kleinera i Władysława Floryana, t. XVII, Wrocław 1975.

20 Por. Jarosław Iwaszkiewicz, Tom XVII, „Życie Warszawy” 1976, nr 121. 
sporządzane na marginesach książki stanowiły wówczas także formę przygotowania do pisania recenzji edycji Króla-Ducha publikowanych przez Iwaszkiewicza w „Wiadomościach Literackich”. Liczne oznaczenia, podkreślenia i komentarze pisarza naniesione na tekst poematu wykonane zostały przy użyciu czarnego pióra, ołówka oraz czerwonej kredki, co może sugerować, że Iwaszkiewicz kilkakrotnie powracał do lektury lub czytał ją w różnych odstępach czasu. $\mathrm{Na}$ stronie tytułowej drugiego tomu Iwaszkiewicz zapisał cytat z Króla-Ducha wraz z jego lokalizacją w tomie pierwszym:

O Panie! Oto mrówki robota

Aniołom twoim wiecznym rówieśna,

Oto jest droga moja boleśna

I tajemnica mego żywota

$$
\text { O. } 239
$$

(t. 1, s. 567)

W kontekście niezwykle precyzyjnej, żmudnej i czasochłonnej pracy edytora nad tekstem poematu Słowackiego cytat ten zyskuje nowe znaczenie. Jego użycie przez Iwaszkiewicza może być próbą podkreślenia zasług edytorskich Pawlikowskich, ale także spojrzeniem na ich pracę $\mathrm{z}$ dystansem i przymrużeniem oka poprzez porównanie edytorów do mrówek robotnic.

W pierwszym tomie ${ }^{21}$ Iwaszkiewicz naniósł ołówkiem poprawki na tekście głównym, modyfikując w ten sposób wymowę fragmentu:

Któremu oto obrusy łabędzie

Jak od jutrzenek zapalone wody

Rumienią [Rumiane] ... [s] Słońcem rumieni [ą] się wszędzie Śród nawiedzonej anielstwem gospody.

Wśród marginaliów pojawiają się też wzmianki dotyczące kontekstów kulturowych i historycznoliterackich. Czytając odmianę 79

21 Juliusz Słowacki, Król-Duch, t. 1-2, oprac. Jan Gwalbert Pawlikowski, Michał Pawlikowski, dz.cyt., t. 2, s. 66. [wyd. rec.]. 
poematu $^{22}$, Iwaszkiewicz skojarzył ją z Balladynq Słowackiego i opatrzył komentarzem: „monolog Grabca”. Przy odmianie $277^{23}$ widnieje natomiast notatka: „Henryk Pobożny i św. Jadwiga”, co szerzej zostaje skomentowane w recenzji dla „Wiadomości Literackich”24.

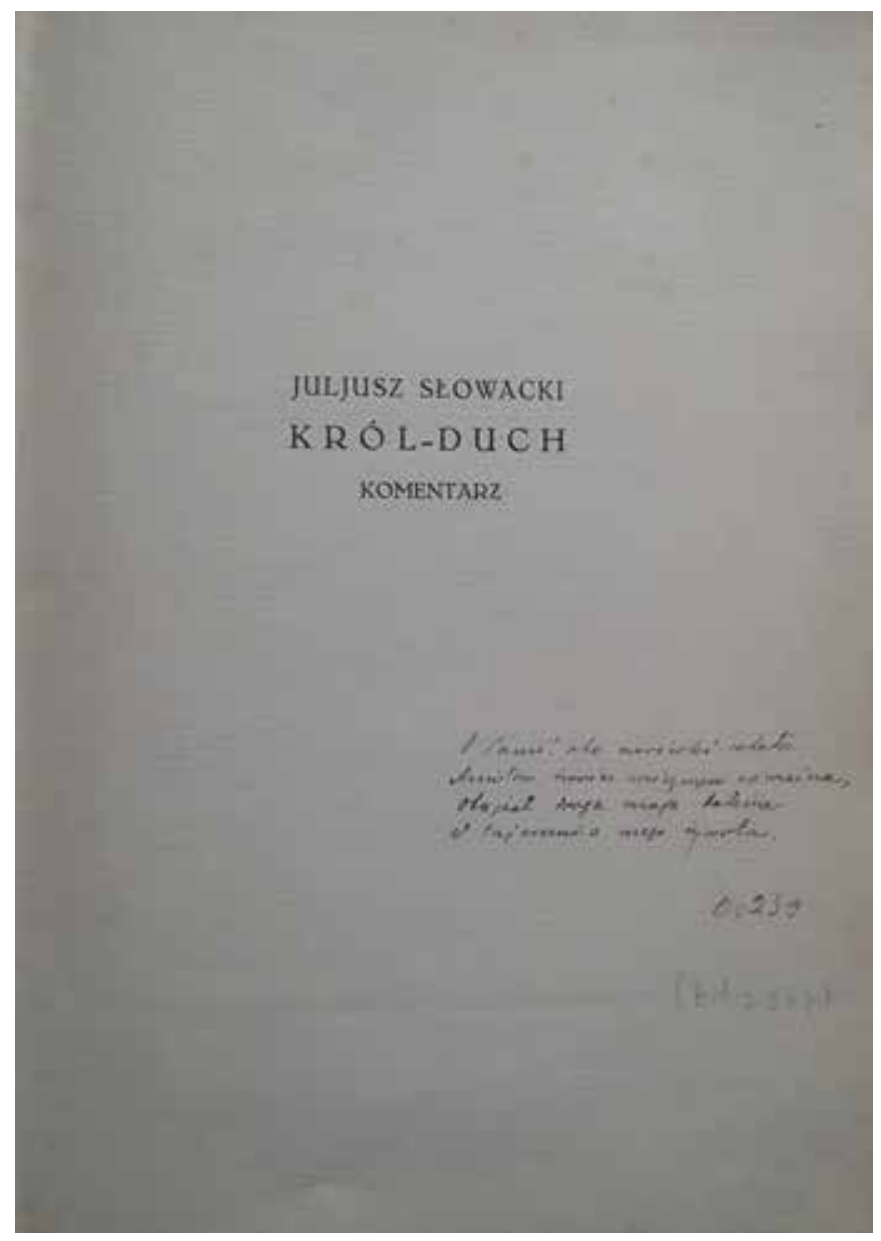

${ }^{22}$ Juliusz Słowacki, dz.cyt., t. 2, s. 343. [wyd. rec.].

23 Tamże, s. 584.

${ }^{24}$ Por. Jarosław Iwaszkiewicz, Wydanie zupełne «Króla-Ducha», dz.cyt. 
$\mathrm{W}$ innym miejscu Iwaszkiewicz podejmuje próbę rekonstrukcji rękopisu, która nie udała się edytorom ${ }^{25}$. Pawlikowscy pozostawili w wątpliwych miejscach znaki zapytania lub luki w słowach:

Wywoływały (?) z d.....(?) tęsknotą

Strzechę (?) - błękitną noc - i gwiazdę złotą.

Iwaszkiewicz nanosi na tekst swoją propozycję odczytania tekstu:

Wywoływały (?) z t.....(?) [dziwaczną] tęsknotą

Strzechę (?) [Strachy] - błękitną noc - i gwiazdę złotą.

Za pomocą marginaliów Iwaszkiewicz prowadzi również dialog z edytorami, sygnalizując swą aprobatę lub dezaprobatę. Zamieszczona przez Pawlikowskich informacja, że strofa 14 (w rękopisie 15) nawiązuje bezpośrednio do strofy $13^{26}$ skomentowana została przez Iwaszkiewicza: „nie!”. Myśl tę rozwinie on później w recenzji ${ }^{27}$.

Kiedy Pawlikowscy uzasadniają użycie przez siebie określenia „przeglądy treści” zamiast stosowanego wcześniej przez wydawców sformułowania "plany Króla-Ducha” ${ }^{28}$, Iwaszkiewicz opatruje ich argumentację adnotacją: „oczywiście”, ale gdy edytorzy nazywają nieukończony dramat Słowackiego Samuel Zborowski „poronionym”29, Iwaszkiewicz stanowczo protestuje, podkreśla ten fragment ołówkiem i komentuje to słowem: „nonsens!”. Określenia „wszystko nonsens” użył również w odniesieniu do propozycji interpretacyjnej dotyczącej ducha Anieli ${ }^{30}$.

Iwaszkiewicz zauważa też i koryguje błędy druku, na przykład brak początkowej litery w słowie „świat”31. Pojawiają się także naniesione jego ręką liczne niekomentowane podkreślenia, zakreślenia, znaki zapytania, pojedyncze lub potrójne wykrzyknienia. Niekiedy

\footnotetext{
25 Juliusz Słowacki, dz.cyt., t. 2, s. 301. [wyd. rec.].

26 Tamże, s. 69.

27 Por. Jarosław Iwaszkiewicz, Wydanie zupełne «Króla-Ducha», dz.cyt.

28 Juliusz Słowacki, dz.cyt., t. 2, s. 423. [wyd. rec.].

29 Tamże, s. 425.

30 Tamże, s. 434.

31 Tamże, s. 274.
} 
PRZEKŁADY - ARCHIWALIA

zaznaczone są także z prawej lub lewej strony pojedyncze strofy lub wersy.

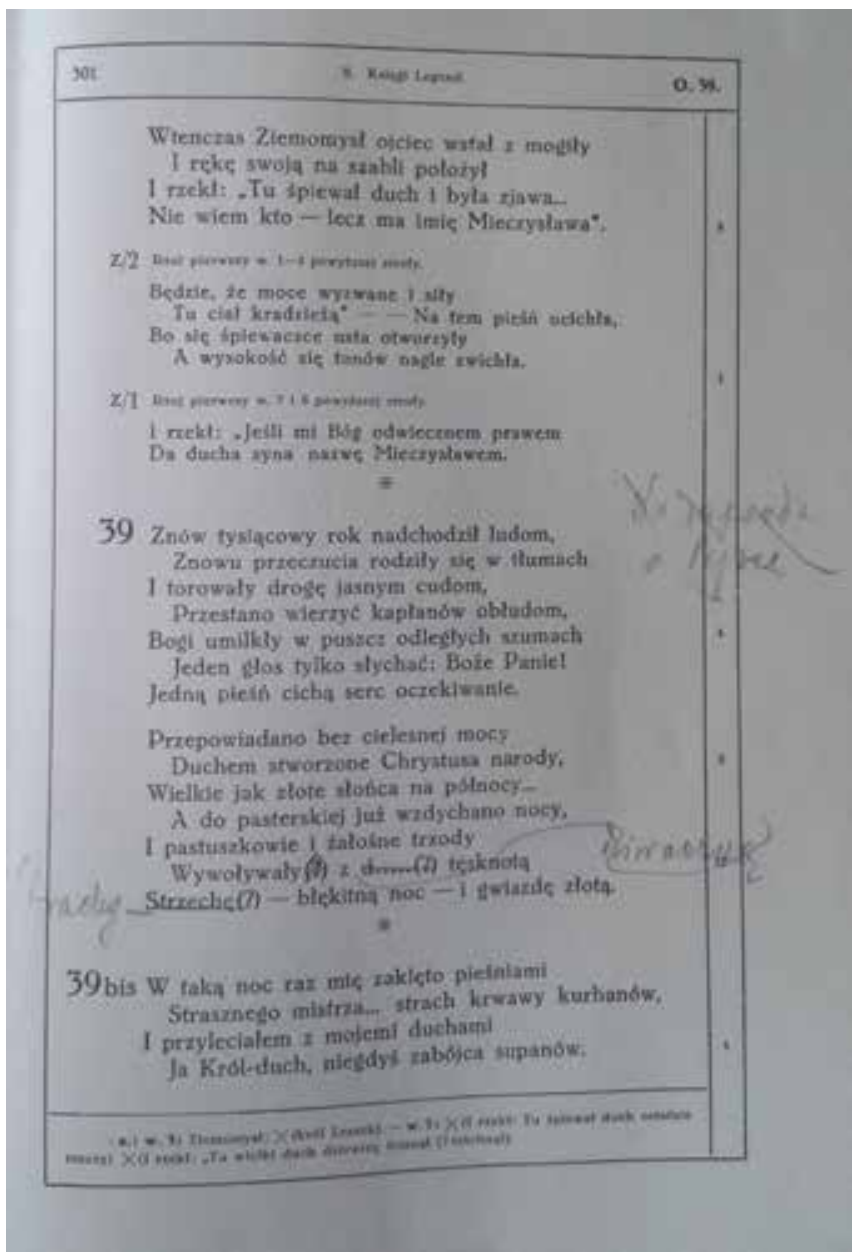


Poniżej zamieszczono trzy artykuły Jarosława Iwaszkiewicza dotyczące Króla-Ducha Juliusza Słowackiego, publikowane na łamach „Wiadomości Literackich”. Zgodnie ze współczesnymi standardami w tekstach zmodernizowano ortografię oraz interpunkcję. Uwspółcześniono również gramatykę (stare formy rzeczowników, przymiotników, zaimków). Kursywą wyróżniono tytuły utworów literackich oraz wyrazy i zwroty obcego pochodzenia. W dwóch pierwszych artykułach zapisano adres bibliograficzny recenzowanej książki w tekście głównym, gdyż tak było w oryginale. Wszystkie przypisy pochodzą od autorki opracowania. 

Colloquia Litteraria

UKSW

2/2015

JAROSŁAW IWASZKIEWICZ

POMNIKOWE WYDANIE KRÓLA-DUCHA*

Juliusz Słowacki. Król-Duch. Wydanie zupełne, komentowane. Ułożył i komentarzem opatrzył Jan Gw. Pawlikowski. Brzmienie tekstów z rękopisów ustalił Michał Pawlikowski. Tom I: Teksty. Tom II: Komentarz. Lwów, H. Altenberg, 1924; str. od IX do XVI i od 1 do 144 (zeszyt A), od 1 do 160 (zeszyt B).

Król-Duch nazwany został, i nie bez słuszności, przez prof. Łempickiego szczytowym dziełem romantyzmu, brylantem, który skupił w sobie wszelkie światła epoki romantycznej, olbrzymią piramidą, zbudowaną na chwałę owych świetnych czasów ${ }^{1}$ Sąd ten może się wydać nawet nadto śmiały, wydaje się nawet taki; sądzę, że przyczyną tego jest kompletna nieznajomość Króla-Ducha wśród naszych nawet czytelników. Toteż głucho jest o nim zagranicą; jedynym przekładem Króla-Ducha na inne języki jest, zdaje się, tłumaczenie na rosyjski Konstantego Balmonta ${ }^{2}$, zapamiętałego wielbiciela i znawcy Słowackiego. Nie wiem zresztą, gdzie i w jakich rozmiarach wyszło ono na światło dzienne, wiem tylko, że istnieje. W swoim czasie Król-Duch był

* Pierwodruk: „Wiadomości Literackie” 1924, nr 47, s. 6.

1 Por. Zygmunt Łempicki, Romantyzm jako jedność i całość, w: tegoż, Renesans. Oświecenie. Romantyzm, Warszawa-Lwów 1923, s. 204-205.

${ }^{2}$ Konstanty Balmont przetłumaczył jedynie część Króla-Ducha zatytułowaną Fragmenty z pogranicza poematu o Helionie i Helois. Por. Juliusz Słowacki, Tri dramy: 1. Balladina, 2. Lilla Veneda, 3. Gelion-«Eolion», tłum. K. Balmont, Moskwa 1911. 
lekturą modną; zapewne więcej mówiono wówczas o Słowackim niż go czytano. Owej „modzie” na Słowackiego zawdzięczamy parę kapitalnych dzieł, zarówno krytycznych, jak i poetyckich: Słowacki i nowa sztuka Matuszewskiego ${ }^{3}$, Mistyka Słowackiego Pawlikowskiego ${ }^{4}$, rapsody historyczne Wyspiańskiego ${ }^{5}$ - oto są owoce kultu Słowackiego sprzed piętnastu, dwudziestu lat. Niestety, kult ten szybko zatarł się i Słowackiego znowu można zaliczyć do prawdziwie zapomnianych poetów. Może to wyglądać na paradoks, ale tak jest. Oczywiście w szkołach wykładają o jednym z trzech wieszczów wszelkie ku tej okazji stworzone banalności, od czasu do czasu zjawia się jakaś praca o Słowackim, pełna wartości, albo nawet wręcz doskonała, jak monografia Kleinera ${ }^{6}$. Jednak brak owego żywego kontaktu społeczeństwa $\mathrm{z}$ dziełami największego artysty, podczas kiedy ten kontakt z tworami Mickiewicza odczuwa się wyraźnie, jakby Mickiewicz po raz drugi żył w naszych sercach i głowach. O ile cała twórczość Słowackiego traktowana jest przez obecne pokolenie $\mathrm{z}$ chłodem, czego dowodem chociażby pewna niechęć, jaką mu okazuje najmłodsza grupa pisarzy, to tym bardziej obcy mu jest ostatni okres twórczości Słowackiego, okres mistyczny. Stosunek pewnej nieufności i pewnego zniecierpliwienia franciszkańską naiwnością ostatniej epoki jego życia odbił się nawet na wspomnianej monografii Kleinera; trzeci jej tom o wiele jest słabszy od poprzednich, a przyznam się, że z lękiem czekam na czwarty - mający ostatecznie rozwiązać pytanie tej pełnej tajemnic fazy. Lękam się, że prof. Kleiner z właściwą mu świetnością otworzy drogę do wszelkich źródeł mistycyzmu Słowackiego, niekoniecznie

\footnotetext{
3 Por. Ignacy Matuszewski, Słowacki i nowa sztuka (modernizm). Twórczość Słowackiego w świetle poglądów estetyki nowoczesnej. Studium krytyczno-porównawcze, Warszawa 1902.

4 Por. Jan Gwalbert Pawlikowski, Mistyka Słowackiego, w: tegoż, Studia nad «Królem-Duchem», cz. 1, Lwów 1909.

5 Por. Tadeusz Sinko, Rapsody historyczne St. Wyspiańskiego, Kraków 1924.

6 Por. Juliusz Kleiner, Juliusz Słowacki. Dzieje twórczości, Warszawa (t. 1 - 1919, t. $2-1920$, t. $3-1923$, t. $4-1927$ ).
} 
zaś może potrafi przeniknąć w istotę psychologiczną niezwykłych przeżyć wewnętrznych tej epoki.

Brak obznajomienia się z całością twórczości Słowackiego i ujrzenia go nareszcie takim, jakim był naprawdę, ma wiele przyczyn wewnętrznych. Przede wszystkim brak jakiegokolwiek odczucia myśli religijnej w naszym społeczeństwie. Biadał nad tym kilkanaście lat temu Brzozowski, powiadając, jak to przeciętny Polak wie, że dzieci i służba chodzą co niedziela do kościoła, no - i na tym wszystko się kończy. Ten brak nastawienia odbija się np. na stosunku do listów Słowackiego, które tyle osób nazywa „kabotyńską książką”, nie spostrzegając najcudowniejszej przemiany pustego, ale wielkiego artysty w świętego człowieka. Listy Słowackiego to jedna z najpiękniejszych i najbardziej wzruszających książek świata. Co prawda w ostatnich czasach zainteresowano się mistycyzmem Słowackiego - w teatrze. Pomijając już samą kwestię szczerości takiego mistycyzmu teatralnego, lękam się, że sceniczna interpretacja (w niepowołanych rękach spoczywająca) tej fazy twórczości Słowackiego może się stać profanacją i znowu zniechęcić ludzi do znalezienia kontaktu z człowiekiem, do którego właściwie należałoby się modlić.

Obok przyczyn wewnętrznych słabego poznania, czym naprawdę jest Słowacki, istniała również przyczyna zewnętrzna - i to dość ważna. Nie mieliśmy bowiem dotychczas zupełnego wydania ostatnich utworów Juliusza Słowackiego. Zaprawdę uważać to można za curiosum, że dopiero w siedemdziesiąt pięć lat po śmierci owa „korona romantyzmu”, genialne dzieło, najbardziej gigantyczny pomysł, jaki się zrodził w głowie Polaka, doczekał się takiego wydania, które można wreszcie czytać. Ktokolwiek czytał Króla-Ducha w wydaniach poprzednich, czy to Gubrynowicza ${ }^{7}$, czy Górskiego $^{8}$, ten przecie przypomni sobie, czym była ta lektura. Pozbawieni najniezbędniejszych komentarzy, nieorientujący się w całości dzieła i w jego liniach

\footnotetext{
7 Por. Juliusz Słowacki, Król-Duch, w: «Dzieła» Juliusza Słowackiego, t. 4, Lwów 1909.

8 Por. Juliusz Słowacki, Król-Duch, w: «Pisma» Juliusza Słowackiego. Zbiór utworów za życia i po śmierci autora, t. 6, oprac. Artur Górski, Warszawa 1908.
} 
wytycznych, sami, z wielkim trudem, musieliśmy się przedzierać przez te góry petitu, aby wreszcie upoić się winem najcudniejszej poezji i wracać na koniec po wielu mękach do poematu tego jak do ojczyzny, rozgwieżdżonej gwiazdami niezapomnianych słów. Rękopisy Króla-Ducha przez siedemdziesiąt pięć lat leżały - dobrze jeżeli w bibliotekach, a nie na strychach domów i lamusów lub w sztambuchach młodych panien - i niektóre $\mathrm{z}$ nich zdołały przez ten czas zaginąć. Zaginęły nawet te rękopisy, które Małecki ${ }^{9}$ miał w r. 1866 w ręku. (Już to nasz stosunek do rękopisów nie jest zbyt subtelny. Sam widziałem w albumie pewnego nawet dość inteligentnego „zbieracza” list Wyspiańskiego, przyklejony zapisaną stroną do karty albumu, a więc przez to zdefektowany!). Resztki rękopisów znajdują się w stanie fatalnym. Miejmy nadzieję, że pomnikowe wydanie, jakie właśnie przedsięwziął Jan Gwalbert Pawlikowski wraz z synem Michałem, wreszcie da nam kompletny i możliwy do czytania tekst Króla-Ducha.

Praca, jaką przedsięwzięli wydawcy, przeraża po prostu ogromem trudności. Po raz pierwszy podany szczegółowy opis rękopisu (a w następnych zeszytach i fotografie) daje nam pojęcie o chaotycznym stanie dzieła, o labiryncie, z którego, niestety, trzeba się wyplątywać nieraz za pomocą cięcia siekiery, czego zresztą Pawlikowski bynajmniej nie ukrywa. Małecki w układzie Króla-Ducha powodował się tylko względami estetycznymi, które go prowadziły na manowce karygodnej dowolności, w oczach naszych częstokroć oburzającej. Następne wydania Króla-Ducha najczęściej są tych dowolności powtórzeniem, czasami z dodatkiem nowych licencji, jak np. tytulatury rapsodów u Górskiego. Wydanie Gubrynowicza, oparte o nową analizę rękopisów, nie uwzględniło tzw. Zielonej księgi, znajdującej się w Bibliotece Krasińskich w Warszawie, było przeto niezupełne. Analiza ta nie była nadto pogłębiona, lecz w każdym razie utorowała drogę Pawlikowskim. Zbadali oni i opisali rękopisy z niezwykłą

\footnotetext{
9 Antoni Małecki (1821-1913) - historyk literatury, językoznawca, filolog klasyczny; przygotował do druku dwutomowe wydanie Pism Juliusza Słowackiego (1880), autor książki Juliusz Słowacki. Jego życie i dzieła w stosunku do współczesnej epoki (t. 1 1866, t. $2-1867$ ).
} 
wprost drobiazgowością. Być może drobiazgowość ta wyda się komu szczytem pedanterii, przy ustalaniu jednak tekstu Króla-Ducha raz na zawsze - pedanteria ta jest wprost koniecznością.

Aby zdać sobie sprawę $\mathrm{z}$ trudności, $\mathrm{z}$ jakimi walczyła ta analiza, trzeba zrozumieć, jaki był proces twórczy Słowackiego w epoce pisania tego poematu. Gigantyczny pomysł przerastał po prostu wyczerpujące się siły umierającego poety; a trzeba pamiętać, iż był to raczej las pomysłów, ze wszystkich stron, jakby z zewnątrz, osaczający poetę i narzucający mu się z nieodpartą, mistyczną siłą. Sposób pisania, szczególniej owo niecierpliwe stawianie kropek, „tak jakby niecierpliwe pióro nie mogło spocząć, kiedy myśl nadążyć mu nie może"10, oraz owo poplątanie kilku stron razem (odmiana 169 i odmiana 181), tak jak gdyby jednocześnie odbywało się w mózgu twórcy parę procesów myślowych, świadczy o olbrzymiej roli, jaką w procesie twórczym Słowackiego odgrywała podświadomość. Król-Duch tworzył się w stanie, który nazywamy transem, tym samym częstokroć poemat nie zawsze mógł być autorytatywnie wyłożony przez samego poetę, skąd powstawały pewne niejasności. Taka niejasność tkwi, moim zdaniem, w wydrukowanym za życia Słowackiego rapsodzie pierwszym; niestety, zaginięcie rękopisu tego rapsodu nie pozwala tu sprawdzić mojej hipotezy, nie mającej zresztą, zdaje się, innego oparcia, prócz źródeł uczuciowych, których krytyka literacka uwzględnić nie może. Otóż wydaje mi się, że słynne zjawienie się Herowi, przebywającemu w zaświatach, dwóch postaci mistycznych, jednej oznaczonej przez Pawlikowskiego jako „umiłowana odtąd i na wieki” - drugiej,

Pani któregoś z ludów na północy.

Jaką judejscy widzieli prorocy,

jest jakby dwiema odmianami, dwoma rzutami tej samej, jedynej postaci. Postać ta, owa „Matka Stworzycielka”, „Matka Miesięcznica” księżyc, Matka Najświętsza, Polska, jest zarazem ową Polską idealną, świętą republiką, której daleka jutrzenka jest przewodnim snem

10 Por. Juliusz Słowacki, Król-Duch, t. 1-2, oprac. Jan Gwalbert Pawlikowski, Michał Pawlikowski, dz.cyt., t. 2, s. 13. 
duchów, dążących do królestwa niebieskiego na ziemi. Uczuciowo trudno nam jest odróżnić Polskę, utożsamioną z Najświętszą Panną, od owej „umiłowanej odtąd i na wieki” świętej przyszłej szczęśliwości. Podział wizji owej na dwie wizje osobne oparty jest na strofie XVI rapsodu I, pieśni 1-ej, a ściśle biorąc na wierszach 124-126, które brzmią:

A wtem jasność przyszła nowa,

I w tym powietrzu jako w diamencie

Ukazał się wid...

Nasuwa się pytanie, czy słów tych nie należy rozumieć jako nadejścia nowego światła, które oświetla na nowo postać dotychczas niejasno widzianą, dokładniej ukazuje ów „wid” - (nie „nowy wid”) i w tym świetle (wewnętrznym) dopiero owa „umiłowana odtąd i na wieki” nabiera cech konkretniejszych, „jako w diamencie”, ukazując się w postaci Polski - Matki Najświętszej. Jeżeliby nawet formalne względy kazały się wyrzec tej hipotezy, pozwala ona nam na przeprowadzenie pewnej jednolitości koncepcji - i ostatecznie pomoże raczej w rozumieniu Króla-Ducha, a jej „dziwne”, jak powiada Pawlikowski, przekształcenie się w hipostazę światotwórczej siły kosmicznej straci cechę dziwności.

Ale to są uwagi na marginesie. Wracając do odbudowy poematu, przedsięwziętej przez Pawlikowskich, należy pokreślić owo opierające się na psychologii twórczości Słowackiego podkopanie „zaufania do rękopisu”, jak to nazywa Pawlikowski. Oczywiście termin ten jest nieścisły, chodzi tu i o głębsze wniknięcie w rękopis i nie branie go "na oko” - podejście od wewnątrz do tekstu, jedyne prawdziwie możliwe podejście. Ostateczne określenie, czym są tzw. odmiany w stosunku do tekstu głównego i jakie jest ich znaczenie, można również uważać za podkład fundamentalny pod ostateczne uprzystępnienie Króla-Ducha jak najszerszym masom czytelnictwa. Że taki cel przyświecał wydawcom, świadczy rozdział komentarza, zatytułowany O czytaniu «Króla-Ducha». Wraz z krótkim streszczeniem poglądów Pawlikowskiego na mistykę Słowackiego rozdział ten stanowi najlepsze wprowadzenie do zaklętego gmachu poematu, podczas gdy obszerne uzasadnienia kwestii tekstologicznych przeznaczone są 
raczej dla fachowców i amatorów. Jeszcze jedna ciekawa praca dokonana została przez Pawlikowskiego, aczkolwiek wychodzi on $\mathrm{z}$ nazbyt sztucznego, zdaniem moim, założenia. Mianowicie w uwagach końcowych do każdego rapsodu wydawca usiłuje silnie związać treść duchową poematu z konkretnym życiem Słowackiego i z całością jego twórczości. Opiera się przy tym na zasadzie rzekomej „mnenu”, czyli pamięci organicznej. „Mnenu”, czyli pamięć organiczna przeszłych żywotów, objawia się fizycznie w prawie biogenetycznym, podłóg którego w autogenezie, tj. rozwoju płodu, powtarzają się stadia filogenezy, czyli rozwoju gatunku. W psychice odbija się ta pamięć przez to, iż kolejne stadia rozwoju duchowego jednostki są powtórzeniem kolejnych przeszłych żywotów. Odwrotnie, kolejne minione żywoty, jakie przedstawia nam Słowacki w Królu-Duchu, są odpowiednikami stadiów duchowych przeżytych przez poetę. Tak rapsod I ma być odbiciem epoki byronizmu Słowackiego. „Jest on jakby epicką projekcją duchowego nastroju tego okresu w przeszłość"11. Z tym twierdzeniem łatwo przychodzi się nam zgodzić, i wdzięczni jesteśmy Pawlikowskiemu za należyte podkreślenie związku ostatniego stadium rozwojowego twórczości Słowackiego z jej początkiem. Zapewne czeka nas wiele niespodziewanych rewelacji z tej dziedziny w czwartym tomie monografii Kleinera. Natomiast nie sposób nam się pogodzić z niezbyt ścisłym paralelizmem pomiędzy Popielem a Słowackim, przeprowadzonym w dalszym ciągu uwag końcowych do rapsodu I. Popiel - pogrobowiec Wenedów, to Słowacki - pogrobowiec Polski, śmierć Wandy to utrata Ludki Śniadeckiej ${ }^{12}$ itd. Widać, że nie zatarły się w wydawcy jeszcze ślady symbolicznego pojmowania poematu. Chociaż się zarzeka, jednak nie w całej rozciągłości stosuje wskazówkę Słowackiego co do czytania poematu - „czytaj z uczuciem dziecka”. Ścisły paralelizm żywotów Króla-Ducha i stadiów rozwojowych psychiki Słowackiego przeprowadzić się nie da bez pewnych

\footnotetext{
11 Por. tamże, s. 139.

12 Ludwika Śniadecka (1802-1866) - nieodwzajemniona młodzieńcza miłość Juliusza Słowackiego.
} 
naciągnięć - i z całą ciekawością czekamy dalszych zeszytów, jak sobie $\mathrm{z}$ tą tezą poradził Pawlikowski w następnych rapsodach.

Także nie bardzo nam po myśli jest twierdzenie o pochodzeniu koncepcji Popiela od Augustyna Thierry ${ }^{13}$ i jego teorii podbojowych; wolelibyśmy może, aby raczej ukazać nam w Słowackim jakiegoś poprzednika Nietzschego. Zwłaszcza stosunek obu wielkich ludzi do idei liberum veto, wielkiej idei, którą Polska wnieść miała do skarbca „genezyjskich” zdobyczy, świadczyłby raczej o niezależności i niesłychanej śmiałości koncepcji Słowackiego, a jednocześnie dawałby pewne ogniwo niezależnego rozwoju myśli ludzkiej od Byrona do Nietzschego. Jednak to są już poetyckie uogólnienia, których się lękać winien filolog; woli on się oprzeć na Thierrym i wskazać na wpływ lektury... Karamzina ${ }^{14}$.

Zatrzymałem się dłużej nad pewnymi uwagami do rapsodu I, stanowi on bowiem główną treść pierwszego zeszytu, jaki się dotąd ukazał. Czekamy z niecierpliwością na następne, które mają być wydane przez czerwcem roku przyszłego. Edycja całości Króla-Ducha będzie zdarzeniem epokowym w dziejach naszej, a może i światowej literatury; miejmy nadzieję, że podnieci ono naszą miłość do Słowackiego, wzmocni żywy z nim kontakt, i owo „świętych obcowanie”, jeden $\mathrm{z}$ najgłębszych dogmatów katolicyzmu, stanie się żywym ciałem w stosunku do jednego z największych polskich świętych.

P.S. Poważne błędy korektorskie (np. w numerach strof) i chwiejność pisowni w pomnikowym wydaniu jest niedopuszczalna.

\footnotetext{
13 Jacques Augustin Thierry (1795-1856) - francuski historyk, który źródeł nierówności społecznych upatrywał w podbojach dokonanych w średniowiecznej Europie. 14 Nikołaj Karamzin (1776-1826) - rosyjski pisarz, publicysta i historyk; autor dwunastotomowej Historii państwa rosyjskiego (wydawanej w latach 1816-1829), opisującej dzieje dawnej Rusi.
} 
Colloquia Litteraria

UKSW

2/2015

JAROSŁAW IWASZKIEWICZ

\section{WYDANIE ZUPEŁNE KRÓLA-DUCHA*}

Juliusz Słowacki. Król-Duch. Wydanie zupełne, komentowane. Ułożył i komentarzem opatrzył Jan Gw. Pawlikowski. Brzmienie tekstów z rękopisów ustalił Michał Pawlikowski, Lwów, H. Altenberg, 1925. Tom I: Teksty. Str. VIII i 608. Tom II: Komentarz. Str. VIII i 492 i tabl. VIII.

Przed rokiem prawie w tym miejscu słowami pełnymi uznania powitaliśmy pierwszy zeszyt pomnikowego wydania Króla-Ducha i omówiliśmy obszernie znaczenie podjętej przez Pawlikowskich pracy $^{1}$. W duszy nie spodziewaliśmy się, aby wydawnictwo to tak trudne - skończone było w terminie $\mathrm{z}$ góry zapowiedzianym. (Wszak na dokończenie pism Norwida czekamy kilkanaście lat) ${ }^{2}$. A jednak Król-Duch ukazał się całkowicie.

Hańba zaprzepaszczenia najważniejszej spuścizny po jednym z największych romantyków świata została po części zmyta dzięki indywidualnemu wysiłkowi J.Gw. Pawlikowskiego. Nie wahał się on przedsięwziąć trudu przewyższającego zda się ludzkie siły, aby rozplątać niezmiernie skomplikowany węzeł, zagadnienie bowiem rękopisu Króla-Ducha - to chyba najbardziej złożone zadanie, jakie kiedykolwiek czekało na wydawcę rękopisów pośmiertnych. Pawlikowskiemu

\footnotetext{
* Pierwodruk: „Wiadomości Literackie” 1925, nr 39, s. 3.

1 Mowa o artykule: Jarosław Iwaszkiewicz, Pomnikowe wydanie «Króla Ducha», dz.cyt.

2 Mowa o edycji Pism zebranych Cypriana Norwida zainicjowanej przez Zenona Przesmyckiego w 1911 r., która nie została ukończona (ukazały się cztery z ośmiu planowanych tomów). Pierwsze pełne wydanie Pism wszystkich Norwida ukazało się w latach 1971-1976 r. w oprac. Juliusza Wiktora Gomulickiego.
} 
pozwala na prawdziwe wynalazki jego głębokie zżycie się ze światem duchowym ostatnich lat Słowackiego i wielka intuicja. Najważniejszą, moim zdaniem, pracą jest ustalenie tzw. tekstów głównych $\mathrm{z}$ wielką rozwagą i ostrożnością, nieraz z wielkimi trudnościami (np. pieśń 1 rapsodu III lub pieśń 1 rapsodu IV). Teksty te - to podstawa pod przyszłe wydanie popularne poematu Słowackiego. Ustalenie przynależności odmian i ich systematyczne zgrupowanie - to druga nie mniej ważna praca, o pierwszorzędnym znaczeniu dla analityka psychologii twórczości Słowackiego.

Nowe zeszyty nie dorzuciły nic nowego pod względem metody i komentarzy, gdyż zasadniczo kwestia ta była postawiona i rozstrzygnięta w zeszycie pierwszym. Ostatnia seria przynosi jednak reprodukcje ośmiu wybranych stron manuskryptu, unaoczniając i czyniąc bardziej namacalnymi trudności odczytania rękopisu. Najlepsze opisy nie zastąpią takich reprodukcji, które pozwalają należycie ocenić ogrom pracy Pawlikowskich i niezapomnianą ich zasługę.

Jeżeliśmy w zeszłym roku mieli niejakie zastrzeżenia co do pokutującego jeszcze tu i ówdzie u Pawlikowskiego symbolicznego, a raczej alegorycznego pojmowania Króla-Ducha, to się te zastrzeżenia prawie całkowicie rozwiały. „Z całą ciekawością czekamy dalszych zeszytów, jak sobie z tą tezą poradzi Pawlikowski w następnych rapsodach"3 pisaliśmy po przeczytaniu komentarzy końcowych do rapsodu I. Otóż, o ile śmiem twierdzić, teza ta, tzn. paralela pomiędzy każdym rapsodem a pewnym okresem życia Słowackiego, w dalszych rapsodach została zatarta i zaniedbana, znajdując na swe poparcie dość nikłe argumenty. Jeżeli coś nas tym razem głębiej zastanowiło, to pewnego rodzaju chwiejność. Oto nie wydaje się nam jasne, jaki konkretny cel powodował Pawlikowskim w jego wydawnictwie. Czy chodziło mu o ścisłe mniej więcej odzwierciedlenie rękopisu in crudo ${ }^{4}$ i podanie do ręki przyszłym komentatorom książki, która by ten rękopis odtwarzała, czy też danie szerokim masom publiczności czytelnego tekstu Króla-Ducha. Wszystko oczywiście przemawia za pierwszym.

3 Jarosław Iwaszkiewicz, Pomnikowe wydanie «Króla Ducha», dz.cyt.

4 in crudo - łac. w stanie surowym, pierwotnym. 
Niezrozumiała jednak wobec tego jest staranność, z jaką Pawlikowski usiłuje wewnątrz niewykończonych rapsodów, a zwłaszcza odmian, które siłą rzeczy są nieuporządkowanymi fragmentami, wprowadzić pewien porządek logiczny. Niestety, Pawlikowski odziedziczył jeszcze po Małeckim - w drobnej oczywiście mierze - pęd do lo g i c z n e g o traktowania tekstu odmian i czasami dosyć nieostrożnie przetasowuje je, przekreśla i poprawia. Przy tym logika ta nie zawsze jest uzasadniona, tak że czasem mamy wrażenie dowolności, przy której jednak czytelnik jest zawsze poinformowany o dosłownym brzemieniu rękopisu.

Że nie jest to zarzut gołosłowny, weźmy dwa przykłady. W odmianie 216 np., w. 9-11, czytamy:

O! wy sny dawne, w których się przyśniła

Ludowi-Bogu na przyszłość grożąca

Antychrystowa potęga i siła...5.

Przy czym w odnośniku znajdujemy uwagę: „w rękopisie stoi (błędnie): Ludowi Boga - na przyszłość grożąca"6. W komentarzu ani w Układzie odmian nie znajdujemy nic absolutnie na potwierdzenie owego lakonicznego „błędnie”. A przecież myśl, wyrażona w rękopisie, jest bardzo jasna: sny, w których się przyśniła potęga Antychrysta, grożąca w przyszłości ludowi Boga, wybranemu ludowi = Polsce. Co znaczy poprawka Pawlikowskiego, i dlaczego ją uczynił? Czy „Lud-Bóg” to jedno pojęcie jak „Król-Duch”? Czy też sny przyśniły się całemu ludowi? Snami w tym wypadku nazywa Słowacki widzenia stanowiące treść poematu. A zatem cały lud jest opowiadaczem Król-Ducha? Koncepcja nowa. Ale przyznam się, że poprawka zaciemnia tekst, który w brzmieniu rękopisu jest zupełnie jasny.

Drugi przykład - odmiana 37. Wydawca skreśla tu jedną strofę pomiędzy 13 a 14 swego wydania. M.in. powodem tego skreślenia jest to, że „strofa 14 (w rękopisie 15) nawiązuje bezpośrednio do strofy 13 ”7.

5 Juliusz Słowacki, dz.cyt., t. 1, s. 546.

6 Tamże.

7 Juliusz Słowacki, dz.cyt., t. 2, s. 69. 
Twierdzenie to jest zupełnie bezpodstawne, i właśnie, gdy się tę odmianę czyta, zwłaszcza „na świeżo”, razi w tym miejscu luka, którą wyłączona strofa, acz miała być zapewne przez Słowackiego zastąpiona inną, w każdym razie zapełnia. Strofa 12 i 13 głosi mianowicie, że: „bywało”, „kapłan pieje”, „kaplica pełna ludu”, „kniaziowie idą”, „lud ganki obsiada”, „słucha”, „czasem osoby staną”, „słychać pieśni”, „widać mary" . Obie strofy napisane są w praesens historicum, użytym dla oznaczenia czynności częstotliwej, zależnym od początkowego „bywało”. Natomiast strofa 14 (w rękopisie 15) rozpoczyna od zdecydowanego czasu przeszłego: „W środku siedzieli” (oczywiście r a z siedzieli) i „guślarz śpiewał”10. Skok ten pomiędzy użyciem dwóch czasów wypełnia doskonale strofa skreślona: „Na takiej uczcie (jakie „bywało” itd.) $\mathrm{r} \mathrm{a} \mathrm{z}^{11}$ Ziemomysłowi śpiewano"12. Strofa ta dla ciągłości tej odmiany jest konieczna i mimo pewnych powtórzeń skreślona jest zupełnie dowolnie i niepotrzebnie, tym bardziej, że znajdujemy ją także w równoległej odmianie 38 .

Być może, że takie i tym podobne błędy są wynikiem racjonalistycznego mimo wszystko stosunku Pawlikowskiego do poematu Słowackiego. Pawlikowski, walcząc o psychologiczność Króla-Ducha, zaniedbuje kompletnie najważniejszą stronę jego, mianowicie - artystyczność. Z tego względu wartości formalne tego genialnego utworu są podkreślone za mało, a częstokroć całkowicie pominięte. Spotykamy się tu nieraz z wyraźnym lekceważeniem pewnych ustępów artystycznych, jak np. wstępu do Księgi legend, o którym dwukrotnie powiada Pawlikowski, że „nie posiada pierwszorzędnych zalet poetyckich"13. Tymczasem wstęp ten zawiera szereg przedziwnej piękności i śmiałości obrazów, z których jeden wystarcza na okupienie całego wstępu, np. ten:

\footnotetext{
8 Cyt. w oryg.: „kaplice pełne ludu”.

9 Juliusz Słowacki, dz.cyt., t. 1, s. 276.

10 Tamże, s. 277.

11 Wyróżnienie Jarosława Iwaszkiewicza.

12 Juliusz Słowacki, dz.cyt., t. 1, s. 291.

13 Tamże, t. 2, s. 296.
} 
Świat cały w strachu - wieściach - Atlantyda

Herkulesowi z rąk pierzchła jak dusza; ${ }^{14}$.

Tak samo obca zdaje się być Pawlikowskiemu dziedzina zewnętrznej formy poetyckiej, po prostu wiersza. Skoro Słowacki np. przedsiębrał dla celów, jak to sam Pawlikowski powiada, „Czysto formalnych, artystycznych"15 poddawanie pewnej formie periodycznej szeregu fragmentów $\mathrm{z}$ różnych rapsodów, widać, jaką wagę do kształtu poematu przykładał. To samo tyczy się wersji tercynowch, o wierszach nierównych itp. Bogactwo i różnorodność tych form, pokrewieństwo ich $\mathrm{z}$ dawniej przez Słowackiego używanymi (np. muzyczna bliskość odmiany 79 i monologu Grabca w akcie I Balladyny), wreszcie kwestia rymu - nie są to kwestie do pogardzenia. Że są one jednak najzupełniej obce J.Gw. Pawlikowskiemu, świadczy komentarz do w. 102 pieśni 1 rapsodu III. „Spotykamy tu znowu używane często przez Słowackiego dla silniejszego podkreślenia myśli powtórzenie tej samej zgłoski [...]"16. Oczywiście chodzi tu o zjawisko „aliteracji”, częste bynajmniej nie tylko u Słowackiego, pilnego czytelnika $E d d y$, której wersyfikacja całkowicie jest oparta na aliteracji.

Wszystko to uwagi drobne - i na marginesie - wielkiego dzieła dokonanego przez wydawcę i owocu długoletniej i wielkiej pracy. Sądzę, że mimo podziwu i wdzięczności, jaką odczuwa każdy za uprzystępnienie czytelnictwu największego poematu polskiego, podobne drobne uwagi przyczynić się mogą do udoskonalenia przyszłych wydań Króla-Ducha.

Tak np. w komentarzach niedostatecznie, moim zdaniem, uwzględniono elementy składowe fabuły Króla-Ducha, na którą składają się jeszcze inne rzeczy, prócz zajmującej głównie Pawlikowskiego nauki genezyjskiej. Uwzględniając z konieczności pierwiastek historyczny, za mało mówi on o śmiałości w jego „przetworzeniu” i dowolnym operowaniu nim nie tyle może dla celów historiozoficznych, ile dla celów artystycznych. Mało słyszymy o elementach magii, które weszły wszak do postaci Pychy i całej jej akcji („kradzież ducha”, „czarowanie

\footnotetext{
14 Tamże, t. 1, s. 274.

15 Tamże.

16 Tamże, t. 2, s. 164.
} 
na górze Zober"). Nie słyszymy o bajce ludowej, która jednak na pieśni 3 rapsodu III tak mocne wycisnęła piętno, iż Słowacki zachował znany powszechnie zakaz brania czegokolwiek w uśpionym królestwie, nawet „pawiego pióra”, chociaż na akcję poematu, w przeciwieństwie do bajki, zakaz ten nie ma najmniejszego wpływu.

W końcu, jeżeli już sobie pozwoliłem $\mathrm{z}$ dowolnością poety w poprzednim moim artykule („Wiadomości”, nr 47) mówić o odczuwanej przeze mnie tożsamości dwóch postaci niewieścich $\mathrm{w}$ rapsodzie $\mathrm{I}^{17}$, to tutaj wspomnę o moim wrażeniu dotyczącym odmian 275 i 277. Otóż, mimo iż wszystko zdaje się świadczyć o tym, że mowa jest w nich o księciu Michale Twerskim ${ }^{18}$, zawsze wyobrażałem sobie, czytając je, Henryka Pobożnego ${ }^{19}$. Jasny wtedy staje się ustęp: „straszny [...] ten, co nad popiołem / Miast pols k i c h ${ }^{20}$ stawał jak ogień czerwony / I z a c h w i a ${ }^{21}$ [...] Mogołem"22, a także owa katedra i pieśń łacińska Stella matutina ${ }^{23}$ w drugiej odmianie ${ }^{24}$. A w matce zbolałej wolej mi widzieć św. Jadwigę ${ }^{25}$ niż kniahinię Annę ${ }^{26}$. Słowo „katy”

17 Mowa o dwóch postaciach mistycznych opisanych przez Słowackiego w Królu-Duchu jako: „umiłowana odtąd i na wieki” (rapsod I, pieśń I, strofa IX) oraz „pani któregoś z ludów północy" (rapsod I, pieśń I, strofa XVI).

18 Michał Twerski - właśc. Michał Jarosławicz (1271-1318) - książę twerski w latach 1285-1318, wielki książę włodzimierski w latach 1304-1318, uznany za świętego cerkwi prawosławnej w $1677 \mathrm{r}$.

19 Henryk Pobożny (1196/1207-1241) - książę śląski, krakowski i wielkopolski w latach 1238-1241; w 1239 r. odzyskał Santok, rozbijając wojska brandenburskie; inicjator sprowadzenia do Polski zakonu franciszkanów; zginął pod Legnicą w walce z Tatarami.

20 Wyróżnienie Jarosława Iwaszkiewicza.

21 Wyróżnienie Jarosława Iwaszkiewicza.

22 Juliusz Słowacki, dz.cyt., t. 1, s. 583.

Mogoł - dawny tytuł władców pochodzenia turecko-mongolskiego panujących w Indiach.

23 Stella matutina - łac. Gwiazda zaranna.

24 Juliusz Słowacki, dz.cyt., t. 1, s. 585.

25 Jadwiga Śląska (1178/118o-1243) - księżna śląska, matka Henryka Pobożnego; kanonizowana w 1267 r. i uznana za patronkę Śląska oraz całej Polski.

26 Anna Kaszyńska (ok. 128o-1368) - żona Michała Twerskiego; kanonizowana w $1650 \mathrm{r}$. 
w strofie 1 odmiany 277 zdaje się mieć znaczenie przenośni, w każdym razie nie Tatarów katujących Michała - wyraźnie świadczy o tym w. 5 i 6 strofy ostatniej: „Mniszki [...] śpiewem zwyciężyły kata”27. Wyobrażenie o Henryku Pobożnym do nas, dziedziców dzieł Matejki i Wyspiańskiego, przemawia bliżej i głębiej. A właśnie Król-Duch jest taką kopalnią, w której każde pokolenie znajdować może bliższe sobie, odpowiadające epoce momenty.

${ }^{27}$ Juliusz Słowacki, dz.cyt., t. 1, s. 585. 

Colloquia Litteraria

UKSW

$2 / 2015$

JAROSŁAW IWASZKIEWICZ

\section{SŁOWACKI I PROUST*}

Gdy spoglądamy na grube tomy dzieł Słowackiego - przerażenie nas po prostu ogarnia przy myśli, jakiego wysiłku kosztowała chorego ciężko człowieka mechaniczna praca, mająca na celu przelanie na niewdzięczny papier chmury gigantycznych wizji, rodzących się w głowie poety. Niepomierna ta praca (jeden Król-Duch tylko!) stoi w zupełnej nieproporcjonalności do wątłego ciała, które ją wykonało. Mimo woli, gdy przebiegniemy obszerne pole literatury, przychodzi na myśl inny człowiek, w sto prawie lat po Słowackim żyjący, którego schorowane ciało wykonało równie gigantyczną pracę, Marcel Proust.

Ta powierzchowna asocjacja pogłębia się w miarę, jak się nad nią zastanawiamy. Zadziwia nas w końcu kompletna analogia tych dwóch żywotów. Obaj pisarze, wychowani a raczej rozpieszczeni, rozpoczynają żywot swój pozą tak miłą i tak młodzieńczą, tak zresztą utalentowaną, że prawie się nie chce wierzyć w ich geniusz późniejszy. (Zdaje nam się bowiem, że te rzeczy się wykluczają). I gdy pod koniec ziemskiej cielesnej kariery nachylamy się nad ich łożem, nie chcemy dać wiary, że to są ci, co uzbrojeni jak dandy szli na podbój świata. Tam samotna cela Słowackiego, klasztorna w swojej surowości, nakaz wytrwania w gasnących oczach i dyktowanie strof Króla-Ducha gasnącymi wargami, strof, niestety, nie końcowych ${ }^{1}$. A tutaj również w pustelni śmierć nad korektami dzieła, które - szczęśliwsze

\footnotetext{
* Pierwodruk: „Wiadomości Literackie” 1927, nr 26, s. 6; publ. pod pseud. Eleuter.

1 Juliusz Słowacki pisał Króla-Ducha w latach 1845-1849, pracę nad utworem przerwała śmierć poety.
} 
od poematu wieszcza polskiego - nosi u spodu słowo $f n^{2}$, gasnącą napisane ręką. Ów rozłam na dwie połowy życia. Jedna - to barwne rozsiewanie czasu, poetyzowanie, koloryzowanie siebie i innych, pisanie $\mathrm{z}$ ambicji, $\mathrm{z}$ daru, $\mathrm{z}$ zawrotów głowy na szczytach Alp czy na szczytach monde'u ${ }^{3}$ paryskiego. Druga połowa - to praca, wytężone wyrzeczenie się, wysiłek trzymający przy życiu tylko dla jednego celu, dla posłannictwa, dla uwiecznienia tego wszystkiego, co z życia jak strzęp pozostało. Olbrzymia, przygniatająca wielkość - ale wielkość „pracą ducha” wypracowana.

Samo porównanie rękopisów À la recherche $d u$ temps perdu $u^{4}$ i Króla-Ducha, który jest także jakimś tajemniczym poszukiwaniem zgubionego w prawiekach czasu, potwierdza analogię. Ta sama nerwowość pisma, wahania, poprawki, starania o doskonałość.

Niestety, dzieło Słowackiego doszło do nas w strzępach. Nie możemy ocenić stosunku jego części do całości i podziwiać doskonałości formy, jak ma to miejsce u Prousta. Natomiast oczywiście Proust musi ustąpić Słowackiemu pod względem wielkości koncepcji, której równej literatura świata od Dantego nie posiadała.

Porównanie moje byłoby powierzchowne, gdybym poprzestał na analogii wewnętrznej dzieła dwu autorów. Mimo że paradoksem się zdaje to, co mówię, istnieje i głębsza, istotniejsza analogia. Zarówno Słowacki, jak i Proust posiadają i d e n t y c z n ą koncepcję osobowości. Dla obu ja jest nie czymś stałym, lecz procesem. Poszczególne fazy tego procesu oświetla zarówno Król-Duch, jak i W poszukiwaniu straconego czasu, $\mathrm{z}$ tą tylko różnicą, iż ciemne przebiegi tego procesu Proust spycha w podświadomość, a Słowacki zamiast kulis podświadomości wprowadza kulisy zaświatowości, co w gruncie rzeczy na jedno wychodzi, choć dzięki temu proces istnienia ja u Prousta przebiega od kolebki do śmierci, u Słowackiego zaś przez kilka poszczególnych żywotów.

\footnotetext{
${ }^{2}$ fin - fr. koniec.

3 monde - fr. świat.

4 À la recherche du temps perdu (W poszukiwaniu straconego czasu) Marcel Proust rozpoczął pisać w 1909 r., a zakończył tuż przed śmiercią - w roku 1922.
} 
Oczywiście pojęcie osobowości jako procesu, w przeciwieństwie do jakiejś gotowości danych z góry stanów duszy, zastanawia nas bardziej w Słowackim i stanowi o jego nieprawdopodobnej intuicji myślicielskiej. Z tej prostej przyczyny, że Proust przychodzi po Bergsonie i jego psychologicznej filozofii, znaczenie jego psychologii jest znacznie mniejsze; analiza proustowska staje się genialną wprawdzie, ale tylko ilustracją metody Bergsona, gdy tymczasem dzieło Słowackiego swą nowością i niezależnością (oczywiście względną) musi budzić głęboki podziw i szacunek. Nie ulega wątpliwości, iż Słowacki jako psycholog doczeka się swojej monografii ${ }^{5}$. Wówczas Król-Duch jako poemat psychologiczny rozwinie się przed nami niby filmowa taśma autoanalizy Słowackiego. Ten sposób widzenia tego wielkiego poematu, najgenialniejszego dzieła Słowackiego, podzielał już J.Gw. Pawlikowski. Niestety, Pawlikowski próbował tłumaczyć autoanalizę Króla-Ducha historycznie, proces kształtowania się bohatera Króla-Ducha, osoby, która mówi ja (jak bohater Prousta), uważał za równoległy do przebiegu faktycznego życia Słowackiego. Tzn., że pierwszy rapsod odpowiadałby młodości Słowackiego, drugi - latom następnym itd., itd. Myślę, że analiza psychologiczna Króla-Ducha odpowiadała specjalnym ugrupowaniom, nawarstwieniom czy kompleksom, kryjącym się w duszy Słowackiego i odbywającym swe procesy jednocześnie. Ze zlewania się i wzajemnego oddziaływania tych elementów powstało ja psychologiczne Słowackiego, rozłożone przecież w Królu-Duchu z subtelnością nie gorszą od Prousta, a ze znacznie większym polotem poetyckim.

Naturalnie psychologizmowi Słowackiego stoi na przeszkodzie jego wyobraźnia, która sprawia, że każdy jego, drobny nawet, proces wewnętrzny uzewnętrznia się nie pojęciem, nie słowem, lecz obrazem, czego nie ma u Prousta. Obfitość naskakujących na siebie obrazów zaciemnia psychologiczną treść rapsodów Słowackiego, podnosząc jednak artystyczną ich wartość do potęgi, której już potem literatura

${ }^{5}$ Książka omawiająca to zagadnienie ukazała się trzy lata po publikacji artykułu Jarosława Iwaszkiewicza: Gustaw Bychowski, Słowacki i jego dusza. Studium psychoanalityczne, Kraków 1930. 
polska nie osiągnęła. Oczywiście w tej potędze, o tym natężeniu u Prousta nie ma mowy.

Pod względem etycznym różnice obu pisarzy są raczej natury formalnej; w czynach jednego, jak i drugiego czynnikiem decydującym jest wiara w sztukę jako w nieśmiertelność. Proust jednak za sztukę uważa jedynie uzewnętrznianie się, skierowanie akcji artystycznej na zewnątrz, Słowacki kieruje się dośrodkowo, do wewnątrz - obaj jednak wierzą w nią głęboko jako w jedyną gwarancję nieśmiertelności. Ta kwestia byłaby może bardziej skomplikowana i wymagałaby dłuższego zastanowienia się, choć niewątpliwie w zarysach swych jest wierna.

\section{Summary \\ Jarosław Iwaszkiewicz's reception of Juliusz Słowacki's Król-Duch}

The article addresses instances of the reception of Juliusz Słowacki's Król-Duch in Jarosław Iwaszkiewicz's life and works; it is based on Iwaszkiewicz's memoirs, diaries, reviews, literary texts, correspondence with his wife Anna, and the marginalia left on the copies of Król-Duch remaining in the poet's archive in Podkowa Leśna. The article also includes a critical edition of the three texts on Król-Duch by Iwaszkiewicz, published in "Wiadomości Literackie" in 1924, 1925, and 1927. The first two texts critically review Słowacki's narrative poem, the third is a literary sketch putting Król-Duch side by side with Marcel Proust's In Search of Lost Time

Katarzyna Gędas (Uniwersytet Kardynała Stefana Wyszyńskiego w Warszawie) - doktorantka na Wydziale Nauk Humanistycznych UKSW, badaczka literatury współczesnej; autorka m.in. opracowania wyboru felietonów Jarosława Iwaszkiewicza Rozmowy o ksiązkach. Nowy wybór z lat 1954-1979 (Warszawa 2010). 